\title{
Effect of Nitrogen Deficiency and Toxicity in Two Varieties of Tomatoes (Lycopersicum esculentum L.)
}

\author{
Noemi Frias-Moreno, Abelardo Nuñez-Barrios*, Ramona Perez-Leal, \\ Ana Cecilia Gonzalez-Franco, Adriana Hernandez-Rodriguez, Loreto Robles-Hernandez \\ Plant Physiology Laboratory, Facultad de Ciencias Agrotecnologicas, Universidad Autónoma de Chihuahua, \\ Chihuahua, México \\ Email: ${ }^{*}$ anunez@uach.mx
}

Received 1 November 2014; revised 27 November 2014; accepted 3 December 2014

Copyright ( 2014 by authors and Scientific Research Publishing Inc.

This work is licensed under the Creative Commons Attribution International License (CC BY). http://creativecommons.org/licenses/by/4.0/

(c) (i) D Den Access

\begin{abstract}
Tomato is one of the most important vegetables cultivated in Mexico. Nitrogen-based fertilizers have greatly contributed to the increase in tomato production; however, the excessive application of this fertilizer may affect yield and fruit quality. A greenhouse experiment was conducted to evaluate the effect of increasing in rates of nitrogen from deficiency to toxic levels. Five $\mathrm{N}$-treatments $(0,15,30,45$ and $60 \mathrm{mM}$ of $\mathrm{N})$ were applied in two tomato varieties, Caballero and Victoria The optimum $\mathrm{N}$ doses for leaf growth in both varieties was $30 \mathrm{mM}$ reaching 13.0 and $13.5 \mathrm{~cm}$ in Caballero and Victoria respectively. At low toxic levels leaf growth was recovered more easily in Caballero than Victoria. Nitrate concentration for the low toxicity treatment was greater in leaf and stems for Caballero than Victoria; conversely nitrate in fruits was higher in Victoria. Final yield per plant was not statistically different between varieties except at the low toxic treatment where Caballero had a yield of $\mathbf{7 8 0} \mathrm{g}$ per plant compared to that of $330 \mathrm{~g}$ per plant of Victoria. Tomato quality was also affected by the applied $\mathrm{N}$-doses, where treatment $30 \mathrm{mM}$ reached the maximum fruit firmness in both varieties while high toxic $\mathrm{N}$-levels decreased significantly this parameter. Soluble solids and titratable acidity increased with increased N-Doses. Caballero variety seems to be more tolerant than Victoria at low levels of $\mathrm{N}$-toxicity.
\end{abstract}

\section{Keywords}

Tomato, Nitrogen, Deficiency, Toxicity

\footnotetext{
*Corresponding author.
} 


\section{Introduction}

Tomato is considered one of the most widely grown vegetables in the world [1]. In Mexico, this crop is among the top four commercial vegetables, yielding 2.39 million tons per year [2]. Nitrogen-based fertilizers have contributed to the increased success in tomato production. Conversely, the excessive application of $\mathrm{N}$ fertilizers may be affecting production and fruit quality. For traditional field production of tomato, it is estimated that the optimal $\mathrm{N}$ fertilizer dose ranges from 110 to $150 \mathrm{~kg} \cdot \mathrm{ha}^{-1}$ [3]. However, the dosing with nitrogen fertilizers has increased considerably in recent years [4]. Some studies have found that $\mathrm{N}$ applications frequently are above $200 \mathrm{~kg} \cdot \mathrm{ha}^{-1}$, significantly affecting the yield of tomato [5]. In commercial greenhouses, the use of N-based fertilizers for tomato often exceeds crop requirements, in some cases, applying more than double the optimal dose of $\mathrm{N}$ [6]. Other studies have found that the growth of tomato plants, in greenhouses, decreases significantly when $\mathrm{N}$ amount reached $50 \mathrm{mM}$, doses considered toxic for cell extension and reproduction [7]. It has also been observed that the doses in excess of nitrogen fertilization can have important effects not only on performance of the crop but on the quality of the fruit In previous studies $\mathrm{N}$ fertilization had significant effect on primary and secondary metabolism of tomato [7]. Increasing $\mathrm{N}$ application increased the concentrations of some volatile compounds, titratable acidity, soluble sugars, and soluble solids, however, decreased the firmness of fresh tomato fruits [8]. The quality of tomato determines the characteristic taste and flavor of the fruit, in general, optimal application of $\mathrm{N}$ improves the flavor and firmness, while excess nitrogen can damage the fruit [9]. Other studies showed that high doses of nitrogen may have a significant negative effect on product quality as taste and acidity [10] and also can directly affect fruit size as is the case of some vegetables as cabbage where applications of $400 \mathrm{~kg} \mathrm{~N} \mathrm{ha}^{-1}$ reduced fruit size by $35 \%$ [11]. In contrary, other authors, [12] and [13] found no effect of increasing $\mathrm{N}$ on the growth and firmness of tomato fruits. So it is not clear if a gradual increase in the dose of $\mathrm{N}$ can affect plant growth and fruit quality. The aim of this study was to evaluate the increase in rates of nitrogen from low levels of deficiency to high levels of toxicity and how they affect the growth and fruit quality of two varieties of tomato.

\section{Materials and Methods}

\subsection{Site}

This research was conducted at The University of Chihuahua Campus Cuauhtémoc, located in the northwestern part of the State of Chihuahua between parallel $28^{\circ} 24^{\prime 2} 25^{\prime \prime}$ latitude north and the meridian $106^{\circ} 51^{\prime} 8^{\prime \prime}$.

\subsection{Germination and Transplantation}

The germination of tomato seeds (Lycopersicum sculentum L.), Victoria and Caballero varieties, was conducted in plastic cones, $10 \mathrm{~cm}$ in length filled with a peat moss substrate. The seeds germinated at room temperature $\left(25^{\circ} \mathrm{C}-30^{\circ} \mathrm{C}\right)$ for 30 days, then were transplanted to the greenhouse, where they grew under controlled environmental conditions with a relative humidity of $60 \%-80 \%$, temperature $27^{\circ} \mathrm{C}-18^{\circ} \mathrm{C}$, average day and night temperatures, respectively. The photoperiod was $13 / 11 \mathrm{~h}$ (day/night) and light intensity of $350 \mathrm{mmol} \cdot \mathrm{m}^{-2} \cdot \mathrm{s}^{-1}$. The plants were transplanted into hard-plastic pots with a volume of 10 liters. These pots were filled with a sandy loam soil. Plants were thinned out to one plant per pot.

\subsection{Irrigation}

Plants were watered three times a week by replacing the volume of water lost by evapotranspiration. The volume of water lost was determined by the average weight loss of two pots at the end of each week.

\subsection{Treatments}

Treatments were prepared at different concentrations of nitrogen making a nutrient solution for each one of the five doses $(0,15,30,45$, and $60 \mathrm{mM})$ using $\mathrm{NH}_{4} \mathrm{NO}_{3}$ as a $\mathrm{N}$ source. Classification of treatments is shown in Table 1.

Treatments of $\mathrm{N}$ were prepared and applied every 15 days according to the method used by [14] for greenhouse tomato. Nitrogen was the only variable nutrient. Phosphorus, potassium and calcium were applied equally to all treatments at the beginning of the experiment and at the stage of rapid growth (30 DAP), at concentrations of $10 \mathrm{mM}$ of $\mathrm{KH}_{2} \mathrm{PO}_{4}$ and $7 \mathrm{mM} \mathrm{Ca}\left(\mathrm{CaCl}_{2}\right)$. 
Table 1. Treatments and doses of nitrogen $(\mathrm{N})$ applied to two tomato varieties.

\begin{tabular}{cc}
\hline Treatment & Dose levels N (mM) \\
\hline 1) Control & 0 \\
2) Low N fertilization & 15 \\
3) Optimal fertilization & 30 \\
4) Low toxic fertilization & 45 \\
5) High toxic fertilization & 60 \\
\hline
\end{tabular}

\subsection{Growth and Leaf Extension}

To carry out the measurement of this parameter, a metric ruler was used. Measurements were taken every six days, from one leaf per plant, from the base of the petiole to the most extended part. The leaves were marked with a thread for tracking.

\subsection{Quantification of Nitrates}

The $\mathrm{NO}_{3}$ analysis followed the method of [15]. A $100 \mu \mathrm{l}$ of the aqueous extract was added to $0.4 \mathrm{~mL}$ of a solution at $10 \%(\mathrm{p} / \mathrm{v})$ of salicylic acid in $96 \%$ sulfuric acid, and $9.5 \mathrm{~mL}$ of $2 \mathrm{~N} \mathrm{NaOH}$. The concentration of $\mathrm{NO}_{3}$ was quantified by colorimetric measurements at a wavelength of $410 \mathrm{~nm}$ against a standard $\mathrm{NO}_{3}$ curve of $\mathrm{KNO}_{3}(50$ $500 \mathrm{mg} / \mathrm{mL})$.

\subsection{Harvest}

Mature fruits were harvested the $1^{\text {st }}, 7^{\text {th }}$ and $13^{\text {th }}$ of October 2012. Mature fruit was considered fruit with deep red color. Fruits of each treatment were placed in paper bags to be transferred to the laboratory for analysis.

\subsection{Fruit Weight}

The fruits were weighed immediately after arrival at the laboratory on an OHAUS Scout Pro SP202 scale.

\subsection{Sampling for Quality Tests}

Six tomatoes, uniform in shape and maturity, from each treatment were collected of three harvests in October, for a total of 18 tomatoes per experimental unit.

\subsection{Firmness}

To determine the pulp firmness, penetration tests were carried on at room temperature using an Electronic Pressure Model TA-XT2i (Stable Micro Systems, YL, England) equipped with a cylindrical steel rode $4 \mathrm{~mm}$ diameter and a plate $80 \mathrm{~mm}$ in diameter for the compression test. For the device configuration, the following characteristics were used: test speed was $2 \mathrm{~mm} \cdot \mathrm{sec}^{-1}$ and the distance between lectures was $10 \mathrm{~mm}$, the values were expressed in Newtons [16] [17].

\subsection{Soluble Solids}

The soluble solids content was measured using an ATC-1D refract meter (Atago Ltd., Tokyo, Japan) with a scale of 0 to $32^{\circ}$ Brix at $28^{\circ} \mathrm{C}$. The procedure for this test was to place a few drops of fruit juice per treatment. To take the reading three drops per treatment were placed in the refract meter.

\subsection{Titratable Acidity}

The titratable acidity was analyzed using a pH meter Hanna HI 422 mark (Hanna Instruments Inc., Woonsocket, RI, USA) with a resolution of $0.1 \mathrm{~mol} \cdot \mathrm{L}^{-1} \mathrm{NaOH}$ titration. Five samples per treatment were performed.

\subsection{Statistical Analysis}

The analysis was conducted using data from the two tomato varieties, Victoria and Caballero, four nitrogen 
concentrations and the control with four replications, a total of 40 experimental units. Data were analyzed in a randomized block design. Duncan Multiple range test with 0.05 significance level was used to compare means. Statistical analysis was performed using SAS version 2003 package.

\section{Results and Discussion}

\subsection{Leaf Extension}

Nitrogen treatments affected the growth of leaf in the Caballero variety. At $30 \mathrm{mM} \mathrm{N}$ leaf extension was optimal with $13.0 \mathrm{~cm}$. The other treatments had similar leaf extension with 11.6, 12.3 and $11.0 \mathrm{~cm}$ for the control, 15 and $45 \mathrm{mM}$ of $\mathrm{N}$, respectively. It was found at $60 \mathrm{mM}$ of $\mathrm{N}$ leaf growth was $8.4 \mathrm{~cm}$, significantly less than the other treatments (Figure 1).

The variety Victoria had similar results as in Caballero. The optimal dosage of $30 \mathrm{mM}$ of $\mathrm{N}$ had the greatest leaf extension at $13.5 \mathrm{~cm}$ while the 0 and $15 \mathrm{mM}$ dosages behaved very similar reaching a leaf extension of 11.5 and $11.6 \mathrm{~cm}$ respectively. The treatment that most affected leaf growth was the high and low toxic $\mathrm{N}$ dosages at $8.0 \mathrm{~cm}$ and $9.5 \mathrm{~cm}$ respectively. It was also observed that the excess of $\mathrm{N}$ fertilizer delayed for one week the maximum leaf growth compared to the other treatments which growth peaked at 44 DDP. The low toxic and high toxic treatments reduced leaf growth by $29.7 \%$ and $40.8 \%$ compared to the optimal dosage (Figure 2).

Relative to the leaf size, some authors [18] found that Nitrogen doses of $200 \mathrm{~kg} \cdot \mathrm{ha}^{-1}$ in tomato field experiments increased leaf size by $50 \%$ when compared to the control with no nitrogen applied. The effect of toxic le-

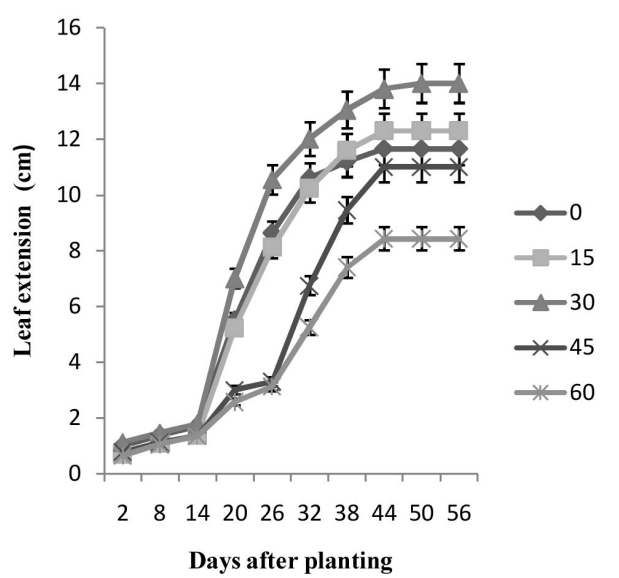

Figure 1. Leaf extension in variety Caballero in response to applied nitrogen treatments ( $\mathrm{mM}$ of $\mathrm{N})$.

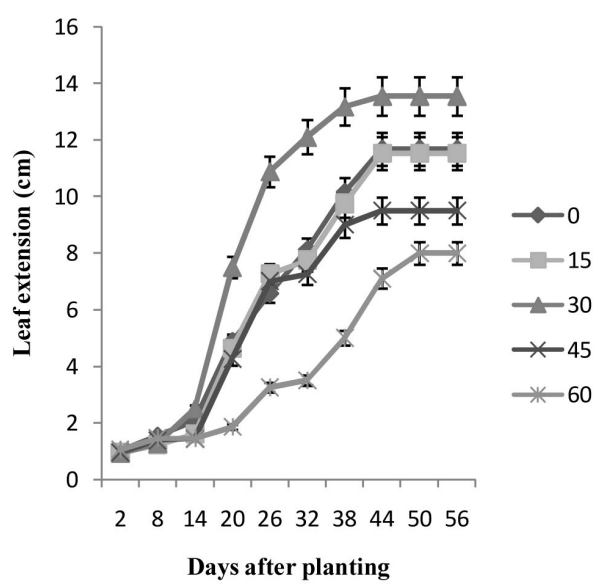

Figure 2. Leaf extension in the variety Victoria in response to applied nitrogen treatments ( $\mathrm{mM}$ of $\mathrm{N})$. 
vels of nitrogen is less clear when plants are cultivated in the field. In the present experiment, the two varieties showed trends in leaf growth, with the variety Caballero being able to recover more easily from the low toxic nitrogen dosage at $45 \mathrm{mM}$, than the Victoria variety.

\subsection{Nitrate Concentration in Leaves}

In the variety Caballero, treatment $45 \mathrm{mM}$ reached the highest nitrate accumulation in leaves at 37,381 ppm, followed by $30 \mathrm{mM}$ at 26,679 ppm. The concentration of nitrate in the $15 \mathrm{mM}$ treatment was $7564 \mathrm{ppm}$. The control and the high toxic dose $(60 \mathrm{mM})$ reached the lowest values with no significantly differences between them. Treatment with $45 \mathrm{mM}$ N reached the highest nitrate accumulation 20,430 ppm in Victoria, followed by $30 \mathrm{mM}$ with 13,856 ppm. Concentration of nitrate in the $15 \mathrm{mM}$ treatment was 10,324 ppm. The control and the high toxic $\mathrm{N}$ dosage behaved statistically alike in both varieties, but different in treatments 30 and $45 \mathrm{mM}$ of $\mathrm{N}$ where Caballero had 48.5 and $45.9 \%$ more nitrates in leaves than Victoria (Figure 3 ).

Other researchers have observed that the rate of accumulation of nitrate in lettuce leaves increased when the nitrogen concentration increased from 60 to $120 \mathrm{~kg} \mathrm{~N} \mathrm{ha}^{-1}$ showing no toxic effect in the plant [19]. The nitrate content in leaves of orchids increased continuously with doses of 10, 20, 30, 40 and $50 \mathrm{mM}$ of $\mathrm{N}$ but only the last treatment (50 mM N) presented an abnormal $\mathrm{N}$-concentration in the leaves [20]. With excess nitrogen fertilization, especially at toxic levels, the most important detrimental effect occurs at the root, reducing the capacity to absorb nitrogen [21]. In the current experiment, the variety Caballero seems to have better tolerance to low N-toxicity stress compared to Victoria.

\subsection{Nitrate Concentration in Stems}

The low toxic Nitrogen treatment reached the highest values of $\mathrm{N}$ concentration in stems of Caballero with 53,241 ppm, followed by 30 and $15 \mathrm{mM}$ of $\mathrm{N}$ with 25,530 and $6543 \mathrm{ppm}$ respectively. Both the control and high toxic treatments were similar, 1032 and 1150 ppm of stem nitrate concentration. Victoria had the highest nitrate concentration in treatment 30 and $45 \mathrm{mM}$, getting statistically similar values. The larger difference between varieties was observed in treatment $45 \mathrm{mM}$ where the variety Caballero had 62\% higher Nitrate concentration in stems than Victoria (Figure 4).

The results of the current study indicate that both the stem and the leaves of the tomato variety Caballero may act as a reservoir for excess nitrogen when applications override the optimum concentration needed for the plant. It was found that increasing nitrate levels in the culture medium can be stored in the stems and leaves of tomato without being easily transported to sites of growth or to the fruit [22]. However, high toxic levels of nitrogen may damage the root system, blocking nitrogen absorption and transport to stems and leaves [23].

\subsection{Nitrate Concentration in Fruits}

Fruit in the variety Caballero reached the maximum concentration of nitrates in treatment 15 and $30 \mathrm{mM}$ with 1250 and $1327 \mathrm{ppm}$. Contrary to the accumulation of nitrates in leaves and stems, the variety Victoria reached a higher concentration of nitrates in fruits than Caballero in most of the treatment. Victoria fruits in treatments 30, 45 and $60 \mathrm{mM} \mathrm{N}$ had 13.4\%, 29.1\% and 24.0\% more nitrate than fruits from the Caballero variety (Figure 5).

They [18] reported that overdoses of nitrogen affected the growth of both leaves and stems but also decrease fruit quality if excessive nitrogen is distributed into the fruits. When comparing the varieties, Caballero appears to have a greater capacity than Victoria to store $\mathrm{N}$ in stems and leaves and less ability to transport it to the fruit.

\subsection{Yield per Plant}

The Caballero variety was not statistically different to the production of the Victoria variety except at the low toxic treatment where Caballero had a yield of 780 g per plant compared to that of 330 g per plant of Victoria variety (Figure 6).

The effect of overdoses of nitrogen on the total production of cucumber (Cucumis sativus L.) was reduced compared to the optimal dose. At the dose of $10 \mathrm{~g} / \mathrm{m}^{2}$ the production was $1.81 \mathrm{~kg} \cdot \mathrm{plant}^{-1}$, while at doses of 20 and $40 \mathrm{mg} \cdot \mathrm{m}^{-2}$ production decreased to 1.65 and $1.23 \mathrm{~kg} \cdot$ plant $^{-1}$ respectively [24]. They [25] in a field experiment with sweet potato concluded that the best yield was achieved with a doses of $80 \mathrm{~kg} \cdot \mathrm{ha}^{-1}$ and $\mathrm{N}$ concentration in fruits did not change at doses between 80 and $120 \mathrm{~kg} \cdot \mathrm{ha}^{-1}$, toxic effects were not observed in the plant. 


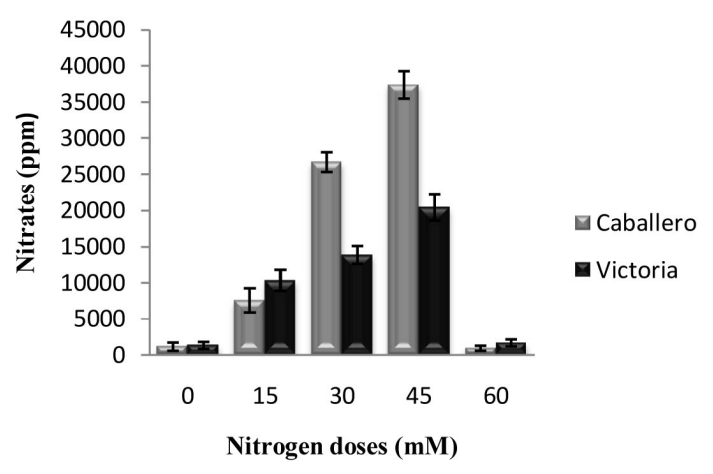

Figure 3. Concentration of Nitrate in leaves of Caballero and Victoria varieties in response to N-treatments.

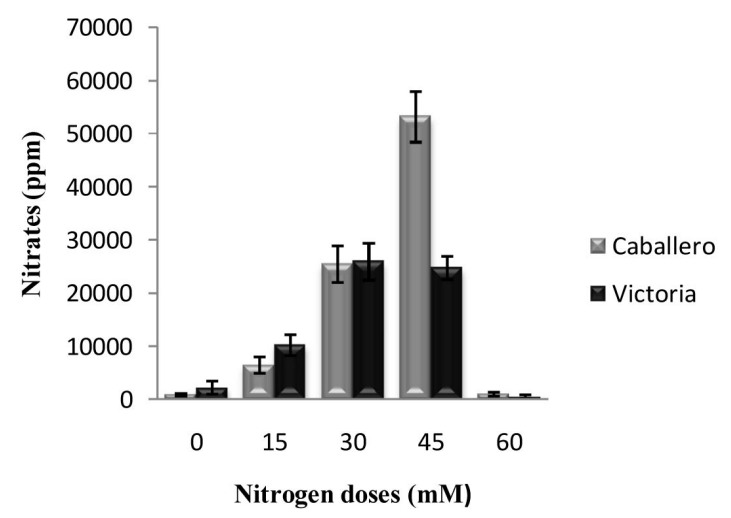

Figure 4. Concentration of Nitrate in stems of Victoria and Caballero varieties in response $\mathrm{N}$-treatments.

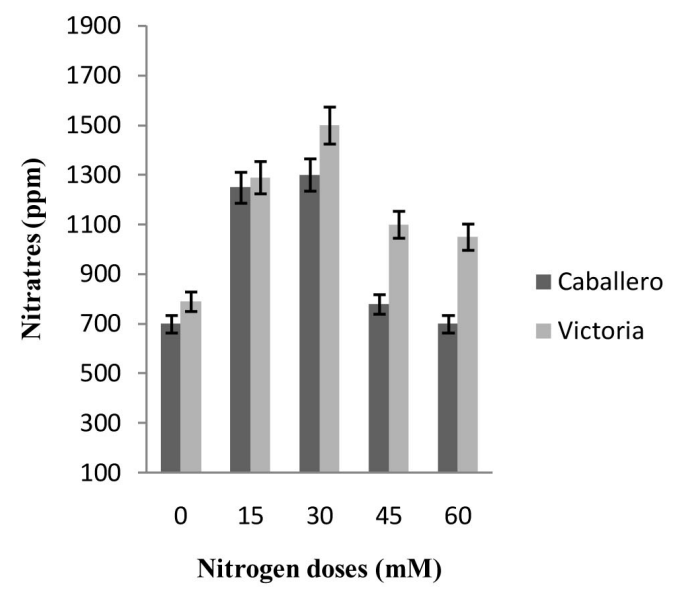

Figure 5. Concentration of Nitrate in fruit of Victoria and Caballero varieties in response to $\mathrm{N}$-treatments.

\subsection{Tomato Quality}

In the current experiment was observed that tomato quality was affected by the different doses of nitrogen. The dose of $30 \mathrm{mM}$ reached the highest yield as discussed above and also the highest fruit firmness in both varieties. Compared to the optimal treatment $(30 \mathrm{mM})$, the high toxic level significantly reduced fruit firmness by $25.0 \%$ and $31.9 \%$ for the variety Caballero and Victoria respectively. Soluble solids and titratable acidity increased with increasing dose of nitrogen as shown in Table 2. 


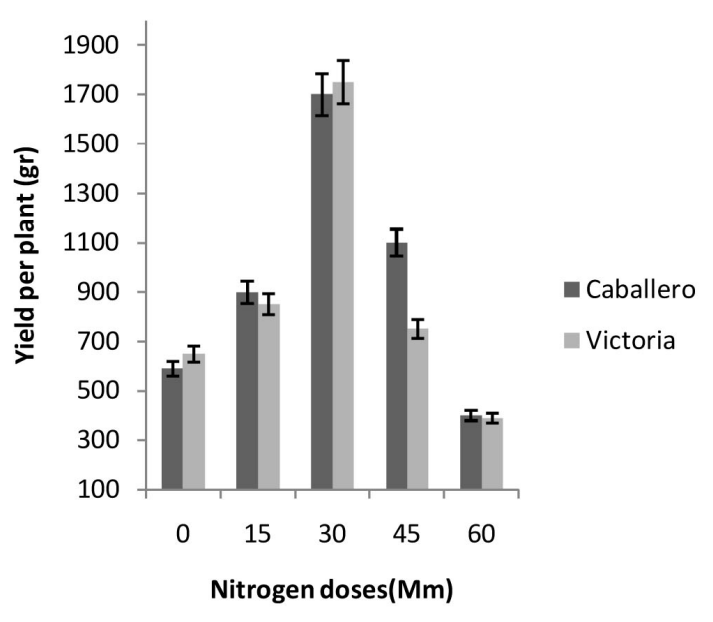

Figure 6. Yield of two varieties of tomato under different Nitrogen treatments.

Table 2. Effect of N-treatments on soluble solids, titratable acidity and fruit firmness in two varieties of tomato.

\begin{tabular}{ccccc}
\hline Variety & N Treatment $(\mathrm{mM})$ & Soluble solids (Brix) & Titratable acidity (\% Citric acid) & Firmness (Newtons) \\
\hline Caballero & 0 & $6.36 \mathrm{a}$ & $0.5496 \mathrm{a}$ & $73.63 \mathrm{a}$ \\
& 15 & $7.61 \mathrm{ab}$ & $0.6678 \mathrm{ab}$ & $61.09 \mathrm{~b}$ \\
& 30 & $9.00 \mathrm{c}$ & $0.7901 \mathrm{~b}$ & $80.66 \mathrm{ac}$ \\
& 45 & $8.76 \mathrm{c}$ & $0.8229 \mathrm{bc}$ & $75.85 \mathrm{a}$ \\
Victoria & $9.81 \mathrm{~d}$ & $0.8992 \mathrm{c}$ & $60.51 \mathrm{~b}$ \\
& 60 & $6.46 \mathrm{a}$ & $0.5346 \mathrm{a}$ & $68.50 \mathrm{a}$ \\
& 15 & $7.33 \mathrm{ab}$ & $0.6428 \mathrm{~b}$ & $72.33 \mathrm{a}$ \\
& 30 & $7.00 \mathrm{~b}$ & $0.6329 \mathrm{~b}$ & $80.64 \mathrm{~b}$ \\
& 45 & $0.75 \mathrm{c}$ & $0.7836 \mathrm{c}$ & $57.00 \mathrm{a}$ \\
\hline
\end{tabular}

Similar results were observed by [10] who reported that the dosages of nitrogen fertilizer increased the soluble solids and acidity in tomato fruits. Other authors [13] concluded that the content of citric acid decrease in fruit of tomatoes grown in soils with nitrogen deficiency. According to [3] concentrations of soluble solids in fresh tomato had a moderate increase after a second application of $\mathrm{N}$ at the time of fruit formation. It was also found that with increasing nitrogen doses increased rates of photosynthesis and soluble solids [13].

\section{Concluding Remarks}

There is a detrimental effect on plant growth and quality of tomato plants with both deficiencies and toxicities of Nitrogen which had a significant influence in decreasing growth, yield and fruit quality in Caballero and Victoria varieties. Caballero had a greater tolerance than Victoria at low toxic doses but no differences were observed at the high doses treatment. High toxicity produced by an excess of Nitrogen applications may have a more detrimental effect in tomato production than deficiencies.

\section{References}

[1] FAOSTAT (2007) Food and Agriculture Organization of the United Nations. http://faostat.fao.org/site/291/default.aspx

[2] USDA (2009) United States Department of Agriculture. http://www.usda.gov/wps/portal/usda

[3] Qi, H.Y., Li, T.L., Zhou, X. and Fu, H.D. (2005) Effects of Different Nitrogen and Potassium Levels on Yield, Quality and Sucrose Metabolism of Tomato. Chinese Agricultural, 21, 251-255.

[4] Hartz, T.K., Miyao, G., Mickler, J., LeStrange, M., Stoddard, S., Nunez, J. and Aegerter, B. (2008) Processing Tomato Production in California. University of California Publications, 7228, 280-298. 
[5] Upendra, M.S., Bharat, P.S. and Rahman, S. (2009) Tillage, Cover Cropping, and Nitrogen Fertilization Influence Tomato Yield and Nitrogen Uptake. Hortscience, 35, 217-221.

[6] Villarreal, M., Hernández, S., Sánchez, P., García, R.S., Osuna, T., Parra, S. and Armenta, A.D. (2006) Efecto de Cobertura del Suelo con Leguminosas en Rendimiento y Calidad del Tomate. Terra Latinoamericana, 24, 549-556.

[7] Cao, W.T. and Tibbtts, W. (1999) Response of Potatoes to Nitrogen Concentrations Differs with Nitrogen Forms. Journal of Plant Nutrition, 21, 615-623. http://dx.doi.org/10.1080/01904169809365429

[8] Christou, M., Dumas, Y., Dimirkou, A. and Vassiliou, Z. (1999) Nutrient Uptake by Processing Tomato in Greece. Acta Horticulturae, 487, 219-223.

[9] Wang, Y.T., Huang, S.W., Liu, R.L. and Jin, J.Y. (2007) Effects of Nitrogen Application on Flavor Compounds of Cherry Tomato Fruits. Journal of Plant Nutrition and Soil Science, 170, 461-468. http://dx.doi.org/10.1002/jpln.200700011

[10] Krueskopf, H.H., Mitchell, J.P., Hartz, T.K., May, D.M., Miyao, E.M. and Cahn, M.D. (2002) Soil Nitrate Testing Identifies Processing Tomato Fields Not Requiring Sidedress N Fertilizer. HortScience, 37, 520-524.

[11] McKeown, A.W., Westerveld, S.M. and Bakker, C.J. (2010) Nitrogen and Water Requirements of Fertigated Cabbage in Ontario. Canadian Journal of Plant Science, 90, 101-109. http://dx.doi.org/10.4141/CJPS09028

[12] Warner, J., Zhang, T. and Hao, X. (2004) Effects of Nitrogen Fertilization on Fruit Yields and Quality of Processing Tomatoes. Canadian Journal of Plant Science, 84, 865-871. http://dx.doi.org/10.4141/P03-099

[13] Benard, C., Gautier, H., Bourgaud, F., Grasselly, D., Navez, B., Caris-veyrat, C., Weiss, M. and Genard, M. (2009) Effects of Low Nitrogen Supply on Tomato (Solanum lycopersicum) Fruit Yield and Quality with Special Emphasis on Sugars, Acids, Ascorbate, Carotenoids, and Phenolic Compounds. Journal of Agricultural and Food Chemistry, 57, 4112-4123. http://dx.doi.org/10.1021/jf8036374

[14] Peet, M.M. and Welles, G. (2005) Greenhouse Tomato Production. In: Heuvelink, E., Ed., Crop Production Science in Horticulture Series, CABI Publishing, Wallingford, 257-304.

[15] Cataldo, D.A., Haroon, M., Scharader, L.E. and Young, V.L. (1975) Rapid Colorimetric Determination of Nitrate in Plant Tissue by Nitration of Salicylic Acid. Communications in Soil Science and Plant Analysis, 6, 71-80. http://dx.doi.org/10.1080/00103627509366547

[16] Grotte, M., Duprat, F., Loonis, D. and Piétri, E. (2001) Mechanical Properties of the Skin and the Flesh of Apples. International Journal of Food Properties, 4, 149-161. http://dx.doi.org/10.1081/JFP-100002193

[17] Wang, J., Teng, B. and Yu, Y. (2006) The Firmness Detection by Excitation Dynamic Characteristics for Peach. Food Control, 17, 353-358. http://dx.doi.org/10.1016/j.foodcont.2004.12.001

[18] Scholberg, J., McNeal, B.L., Kenneth, J.B., Jones, J.W., Locascio, S.J. and Olson, S.M. (2000) Nitrogen Stress Effects on Growth and Nitrogen Accumulation by Field-Grown Tomato. Agronomy Journal, 92, 159-167. http://dx.doi.org/10.2134/agronj2000.921159x

[19] Boroujerdnia, M., Ansari, N.A. and Dehcordie, F.S. (2007) Effect of Cultivars, Harvesting Time and Level of Nitrogen Fertilizer on Nitrate and Nitrite Content, Yield in Romaine Lettuce. Asian Journal of Plant Sciences, 6, 550-553. http://dx.doi.org/10.3923/ajps.2007.550.553

[20] Ruamrungsri, S., Khuankaew, T., Ohyama, T. and Sato, T. (2014) Nitrogen Sources and Its Uptake in Dendrobium Orchid by ${ }^{15} \mathrm{~N}$ Tracer Study. Acta Horticulturae, 1025, 207-211.

[21] Herak, M., Horvati, M. and Pecin, M. (2009) Nitrogen Fertilization Influences Protein Nutritional Quality in Red Head Chicory. Journal of Plant Nutrition, 32, 598-609. http://dx.doi.org/10.1080/01904160802714987

[22] Ezzine, M. and Ghorbel, M.H. (2006) Physiological and Biochemical Responses Resulting from Nitrite Accumulation in Tomato (Lycopersicum esculentum Mill. cv. Ibiza F1). Journal of Plant Physiology, 163, 1032-1039. http://dx.doi.org/10.1016/j.jplph.2005.07.013

[23] Kanchanapoom, K., Anuphan, T. and Pansiri, S. (2014) Effects of Total Nitrogen and Ba on in Vitro Culture of Phalaenopsis. Acta Horticulturae, 1025, 243-245.

[24] Ruiz, J.M. and Romero, L. (1999) Cucumber Yield and Nitrogen Metabolism in Response to Nitrogen Supply. Scientia Horticulturae, 82, 309-316. http://dx.doi.org/10.1016/S0304-4238(99)00053-9

[25] Okpara, D.A., Okon, O.E. and Ekeleme, F. (2009) Optimizing Nitrogen Fertilization for Production of White and Orange-Fleshed Sweet Potato in Southeast Nigeria. Journal of Plant Nutrition, 32, 878-891. http://dx.doi.org/10.1080/01904160902790358 
Scientific Research Publishing (SCIRP) is one of the largest Open Access journal publishers. It is currently publishing more than 200 open access, online, peer-reviewed journals covering a wide range of academic disciplines. SCIRP serves the worldwide academic communities and contributes to the progress and application of science with its publication.

Other selected journals from SCIRP are listed as below. Submit your manuscript to us via either submit@scirp.org or Online Submission Portal.
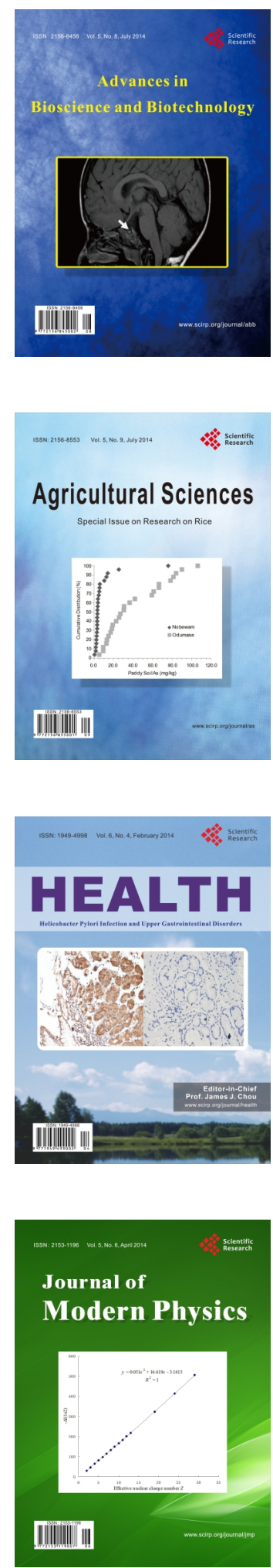
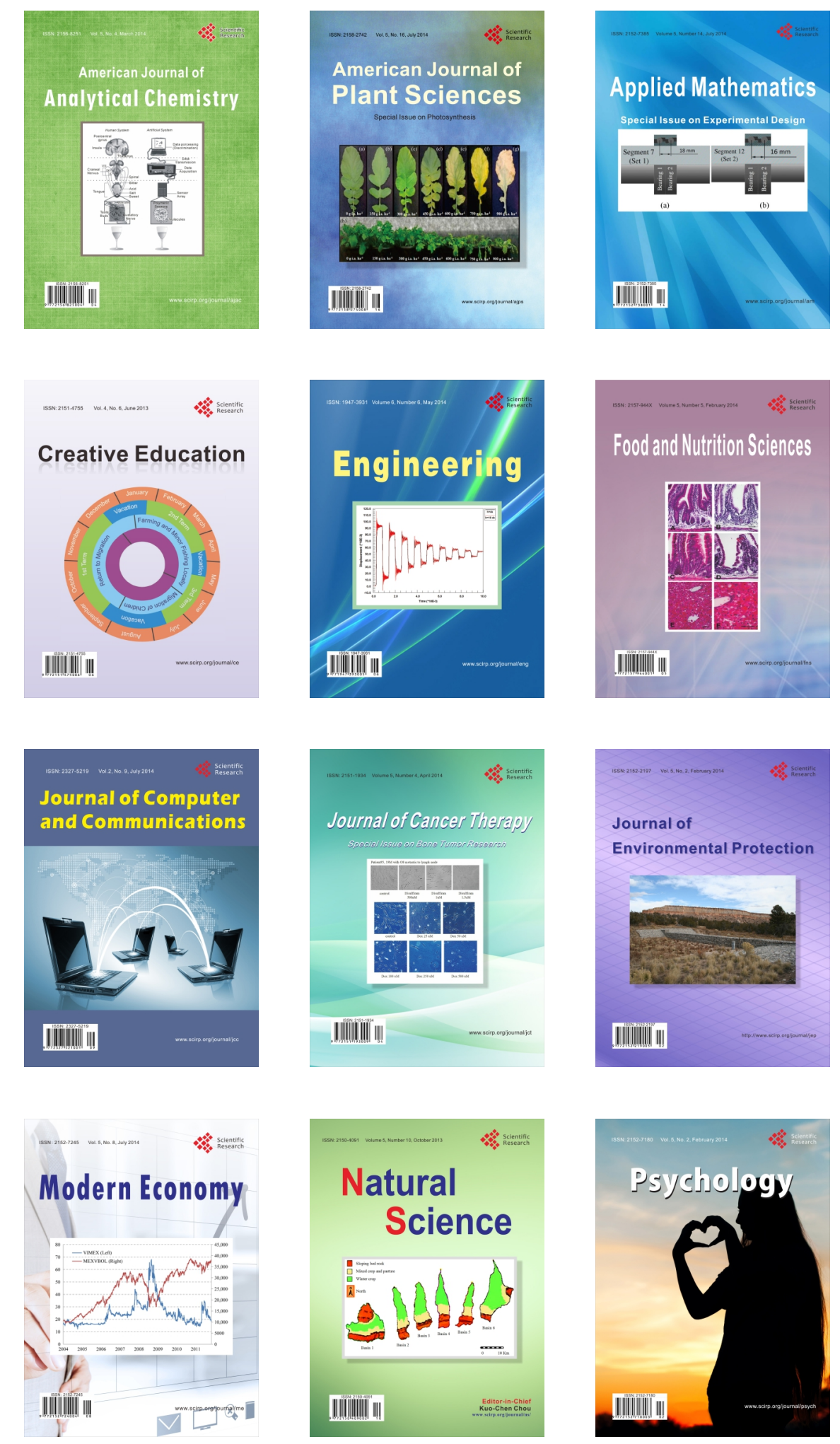